\title{
Paredes Poéticas
}

Eram apenas quatro paredes e não muito altas. Paredes antigas, úmidas e insólitas. Através delas se confundiam a primeira e a última camada de tinta, ambas, baratas e pintadas às pressas. Tinta escusa, fugidia e melancólica. Cor aplicada por um pintor indubitavelmente inexperiente. Assim, o tempo, sucumbiu as vezes do suposto artesão. Ele revestiu o tom precedente pela pele do pó misturado à grossa argamassa que aguardava certamente uma outra cor e, quem sabe?, definitiva e bonita. Uma pintura toda nova e dessa vez bem feita! A tinta seria... branca. É a mais em conta. Paga-se menos e o resultado é melhor. As paredes parecem novas, limpas e zeladas. O branco faz-se como uma promessa de esperança e vida nova e, assim, o seu convite ao nascimento das coisas que vingarão, através das paredes pintadas.

Branca, a cor primeira como é a de uma folha de papel. Folha branca, antes de seu esquecimento no fundo da gaveta de um velho criado-mudo. Folha e branca antes de serem assoladas pelo abandono e, mais tarde, abraçadas pela longa idade de uma aranha que fora menina, moça, adulta e, agora, uma velha senhora sobre a primeira brancura daquela folha inutilizada. Desse modo um amarelo pálido fez-se como um segundo tom... $\mathrm{O}$ tom que o tempo tem e assume de maneira heterogênea sobre o que antes era caiado e limpo. Agora, no entanto, era apenas a vida sossegada de uma teia que cresceu à mercê de uma outra vida no interior daquelas paredes.

Ali o esquecimento penteava demoradamente a franja da poeira. No começo uma poeirinha discreta e devagar agora, contudo, espessa e pegajosa como também são os anos acumulados por um recendente odor, e que se afirma em quase tudo que envelhece quando sob a força inefável do tempo... quando pela desassistência do sol ou a ausência do vento da manhã é o tempo quem ganha a vida e a toma para dentro de si mesmo. $\mathrm{O}$ tempo engorda. A poeira se faz pele e a parede (tanto quanto uma folha de papel) perde a sua brancura.

O que seria do quarto se houvesse pelo menos uma janela? Uma única e grande?! O que seria desse quarto quando o sol atravessasse o cômodo e 
se instalasse no peito da parede maior? Depois cansado o sol descansar-seia no corpo do chão e, ali, a visita de uma borboleta ou de um passarinho sem ninho e, desse modo, a gratuidade da vida num gesto de beleza singela, imprevista e altruísta.

Longe de outra mão humana faltaram ao criado e à gaveta o toque pelo tecido de uma flanela e o zelo pelo lustro depois do uso da cera. Faltou à folha branca um sopro... por aquele que não a usou para subscrever uma carta ou assistir ao nascimento de um poema... e o poema compreende melhor que a vida resiste também quando não se é usada e passa, esquecida, sem que alguém se aperceba que, ali, dormia uma folha e que ela sobrevive de silêncios e ausências... e que uma folha branca conta as ausências daquele que partiu e que não volta.

Sua brancura-amarelada tem a cor estrangeira da palavra que se não s'inscreve porque é no corpo quotidiano que o texto nasce, cresce, apaga, reescreve as pelejas, os presentes, as perdas, os ganhos, as descobertas, os sustos, as promessas, as traições, o imaginário e as realidades...

À semelhança de um rosto humano as paredes daquele quarto perderam a lisura inicial e, talvez, por isso, ganharam, uma pele enrugada, umas tantas fissuras, outras marcas e muitos vincos como acontece com vida humana e quanto mais desumana.

Aquelas paredes evocavam um gasto soneto que em um outro tempo, talvez, teria sido escrito sobre uma mesa com toalha bordada e, ao lado, uma taça de chá servida na peça em porcelana branca e azul ou, simplesmente, num caneco com café pela água da chuva, pois que mata melhor a sede... e, assim, sobre a mesa, a folha, que fora muito antes a parte oculta que existiu numa madeira sem lei e sem prestígio num canto da floresta...

Quem sabe se noutro tempo o tal soneto fora lido, em voz alta, no gabinete de leitura do bairro, no teatro popular da esquina ou na intimidade da casa, onde passavam amigos e vizinhos para as noites de sarau...quem sabe?

Todavia o teatro teve suas portas fechadas. $\mathrm{O}$ gabinete foi engolido por uma livraria qualquer. $\mathrm{O}$ bairro desapareceu como quis a especulação imobiliária urbana e, assim, o nascimento de outras tantas paredes... Paredes cinzas. Paredes pálidas. Paredes de um amarelo tímido e tristonho. Paredes de pedra. Paredes de um edíficio...

O soneto atarda sossegadamente como dormem as letras das palavras quando caducam e desaparecem também os sons das canções que não se ouvem mais, desde o sumidoro das vozes antigas que cantavam e contavam histórias noite adentro... vida afora... 
Eram paredes vencidas como alguém que se perdeu, e de si mesmo... A tinta desbotada de tanto cansaço, de tanta entrega, de tanta espera. Nenhum sinal, a priori, embora as paredes desvalecidas não tenham assistido ou sofrido, elas mesmas, uma disputa ou um combate ao longo da vida. [Há combates que se fazem silêncio... ]

Eram apenas os sinais do desdém e do desmazelo... 'naquelas paredes. Desprezo e descuido a que estavam subjugadas durante anos e anos e, assim, o tom sem vida e sem alegria como cor de tinta! As paredes persistiam descascadas ali e acolá, acima e abaixo, atrás da porta e entre os cantos... E apenas os olhos sensíveis que têm os artistas veriam naquilo tudo: um estilo ou um vestígio da arte abstrata, aquém das mãos do homem e além dos mistérios da própria vida. As marcas de mofo comiam as paredes acima do rodapé.

[Minha mãe diria: a falta que faz uma boa faxina!]

A ausência do feminino. A ausência de seu oposto. A ausência da combinação entre os dois. $\mathrm{Ou}$, ao contrário, a presença afirmada de um outro feminino e masculino, mas muito longe das convenções e dos códigos de sociabilidade nas sociedades ditas "ocidentais".

$\mathrm{O}$ aspecto sombrio e carregadamente umbroso não vinha do inquilino que pagava corretamente o quarto e se refugiava ali dentro. Era apenas porque o sol não penetrava. Faltava luz! O prédio da frente impedia o exercício da quinta grandeza pela força na vida do astro-rei! Faltava, portanto, o ânimo que nasce através daquilo que a gente sente na pele, na carne e no ventre e que vem da estrela solar. Ela ou ele - sol é o seu nome - embora ela ou ele - estrela viandante - viajou de tão longe... tão longe, atravessou tantas fronteiras, salvo, uma: a dos arquitetos, engenheiros, urbanistas e políticos que não conversam com as estrelas e, portanto, desconhecem os segredos dos planetas, ignoram os sóis, bradam contra as luas e subestimam as vidas cósmicas em reflexo e interlocução com a Terra. Por isso eles todos têm ideias tão tristes e tão monótonas, as quais terminam por empacotar as vidas humanas em quartos sem janelas... e prédios sem a luz generosa do sol.

Nas paredes os poucos sinais de uma vida anterior vinham precisamente de uns tantos buracos, marcas e manchas. Estes, sim, os únicos indícios que, um dia, aquelas paredes teriam servido para acolher um sofá ou teriam, talvez, sustentado dois quadros, um espelho, um porta-retrato, um crucifixo, um almanaque antigo e um porta-casacos.

Tratava-se apenas de um conjunto: quatro modestas paredes como tudo o que havia naquele pequenino quarto irregular, nem quadrado, nem retângulo, cujas paredes tortas e frias reiteravam o aspecto precário do 
lugar. Em uma delas apenas uma janela basculante. Nenhum aquecedor interno e quase nenhuma mobília para disputar o espaço entre uma mala, uns livros, um colchonete, um tapete, algumas roupas de cama, uma mesa de cabeceira, um rádio, um fogareiro, alguma louça, uma cafeteira, duas ou três panelas, uns talheres, uma pia minúscula, uma mesa de canto e, abaixo, de um lado, a lixeira e, do outro lado, duas caixas em papelão destinadas aos mantimentos e aos produtos de limpeza.

Noutro canto do quarto a vizinhança cordial entre uma toalha de banho e uma de mão, ambas, expostas acima de um minúsculo lavabo e, acima dele, um espelho, cuja parte móvel era a face de um pequeno armário, o qual continha: um sabonete, um copo, uma escova, a pasta dental, o barbeador, a loção de banho, uma tesoura, um pente e alguns medicamentos. Dois ou três passos em recuo, logo, o centro do quarto e à esquerda, num canto, as vezes de uma "cozinha" e lá o descanso de dois panos de prato e, acima da porta, uma corda, onde esticados e esquecidos viam-se pendurados alguns pares de meia, duas cuecas e uma camisa.

$\mathrm{O}$ quarto fora readaptado. Pertencera, numa outra estrutura, ao que nas décadas de cinquenta e sessenta era conhecido como "hotel familiar" ou "casa de pensão". Extinto o negócio, o imóvel ganhou nova função e sofreu reformas, embora imperceptíveis naquela altura da vida.

O edifício parecia sustentado por algum milagre da engenharia civil. Havia inúmeras falhas nas paredes, problemas elétricos, o elevador que há anos não funcionava, a falta de manutenção, seu estado insalubre e o aspecto lúgubre, desde à entrada até o último pavimento. Não havia banheiro no interior dos apartamentos. As salas de banho eram coletivas e, geralmente, no fim ou no meio dos estreitos corredores em cada um dos cinco andares do prédio.

Moravam no local sobretudo imigrantes (ilegais ou não), desempregados, excluídos de toda sorte, embora muitos deles pagassem somas importantes ao senhorio. Este, no entanto, não exigia quase documento nenhum e sequer um fiador! O cortiço possibilitava a proteção mínima contra o inverno, contra a violência de rua e uma suposta denúncia anônima. Como domicílio fixo ele abria a possibilidade de percebimento de algum benefício social e a condição mínima para comprovar a residência no país e, assim, poder ser assistido por alguma organização e, através dela, a obtenção de um trabalho remunerado.

O quarto foi alugado com alguma dificuldade pelo inquilino - Johann Mahdi - um ano depois de sua entrada na cidade da luz! Seus companheiros chamavam-no: Johnny. Vinham para jogar cartas e, na oportuna ocasião, esvaziavam latas de cerveja e, nos dias melhores, algumas garrafas de 
vinho. Pelo estado do quarto estiveram, ali, a noite passada e, talvez, até um pouco antes da minha chegada.

Quando entrei pela primeira vez no quarto não pude conter o meu espanto. Fui traída pela mudez e pela sensação fria que me percorreu todo o corpo e se estampou como uma segunda pele na pele inexperiente do meu rosto... O susto foi, contudo, logo transformado em admiração. A curiosidade foi o que, de fato, me conduziu até aquele homem. No entanto, naquele momento, foi a sua coragem e a sua dignidade que se revelavam diante de mim. Ultrapassei desse modo os meus limites, a minha fragilidade e o meu... temor.

Além das paredes habitavam, ali, um espírito, uma alma e uma consciência generosa, embora aguerrida, dura, pedra, como muitas vezes é a dor em estado de silêncio.

Eu pouco sabia sobre a sua vida, mas o lugar evocava uma outra experiência e, por mim, bem conhecida. Pela memória a minha lembrança sobre aquelas noites quando estive com outros refugiados, imigrantes e "nacionais" sem domicílio fixo...

$\mathrm{O}$ seu quarto era de algum modo tão parecido com aquele outro quarto, anônimo e clandestino, onde eu havia dormido há uns tantos anos atrás. Aos poucos ele se tornou tão familiar e, por isso, a nossa condição estrangeira - a minha e de Johnny - tornou-se uma ponte... Ponte invisível entre o seu mundo e o meu e, ali, no meu do mundo, no sul do nada, lugar nenhum, o nosso começo e o nosso encontro...

À sua maneira de ser uma explícita declaração de sua imensa sensibilidade e rica interioridade. A forma de uma expressão "semântica" (?) pintada em verbo, em substantivo, em matéria poética, reflexiva, política, estética e, particularmente, anímica. As paredes do fundo recobertas de impressões, percepções, sentimentos, desenhos, recortes de jornais e revistas, fragmentos de frases e... pensamentos misturados ao mofo, aos buracos da parede, à tinta antiga, às marcas de envelhecimento do quarto e, assim, no meio disso tudo, a linguagem desse homem como pintura nova...

No peito da segunda parede, à frente do basculante que fazia as vezes de uma janela... a surpresa... a sua poesia revestida tanto pela revolta e pela angústia, quanto pela lucidez que vem da dor, do amor, da cólera, da desesperança, do desejo, da fé, da perplexidade e da simplicidade humana em Johnny que é feminino e masculino, como também, são a beleza e a filosofia abraçadas num nascimento improvável pelo corpo de uma escrita estrangeira, através daquele homem e de suas mãos, durante suas elucubrações em noites altas. 
Nas paredes uma espécie de metalinguagem constituída por inúmeros significados, significantes, expressões, imagens e desabafos, os quais recombinados traduziam parte de seu universo. Um cosmos desconhecido, misterioso e parcialmente descoberto. Todo um discurso feito de um grito ininterrupto e solitário... O passado engolindo e refazendo o presente. Suas leituras apontadas como pensamentos avulsos sobre, através e pelos muros... muros ou paredes quando substituem cadernos ou folhas.

Assim, pela escrita, uma linguagem refugiada às luzes de Paris.

As paredes como... um espelho e pelos quatro lados: a visão do mundo ou de um certo mundo dentro de um homem, antes, ele mesmo, militante, agora, exilado político, anônimo, sem armas, sem presente, mas com o passado e, dele, pela escrita, a sua forma de escritura, embora torta, poética, latente, política... como o seu suporte... paredes tortas, num mundo torto, políticas tortas, vida latente, alma poética tanto fugaz, quanto solitária.

As paredes emitiam vozes, escondiam rostos, confessavam idades, confabulavam histórias e permitiam a redescoberta sobre o sentido das palavras que os jornais não contam. Por detrás delas a dissensão, a incompletude, o desejo, o grito, a mudez, o silêncio, a leitura, a solidão, a liberdade, a escrita, a alegria, a luta, a tristeza, a surdez, a reflexão, o pensamento, o vazio, o todo, o exílio, a dor, a melancolia, a alegria, os contra-sensos da vida e, no próprio homem, a força, a coragem, uma resistência como a arma sem a morte e, dela, a sua própria dignidade numa sobrevivência improvável entre a luta em seu país e o combate (que pode ser tantas vezes uma vida humana) na conquista de um dia após o outro e um outro e um outro.

As quatro paredes e o teto substituíam um suposto caderno de viagem... E como um livro aberto, mas sem edição ou, talvez, apenas uma história sem quadrinhos: as suas folhas avulsas e em desordem. A sua ordem sobre a desordem do mundo e, por meio dessas folhas sem folhas, desse livro sem livro, apenas nas paredes o que me foi possível ler e reler sobre uma parte das ideias e do seu protocolo de leitura... A leitura da memória.

Dentre os livros lidos algumas frases recopiadas das obras emprestadas, através da biblioteca do bairro e, também, por meio das manchetes e das notícias recortadas e coladas aqui e acolá. Desordenadas. Ordenando. Recombinando. Ultrapassando os limites das fronteiras. Tantas. Muitas. Visíveis e invisíveis.

$* * *$

Eu gostaria de ter mãos conscientes para o uso das cores e mãos hábeis para o desenho. Mãos de artista como, por exemplo, as mãos de 
Fernando Diniz: o menino pobre sem brinquedo na Bahia, o homem rico do universo inconsciente pelas mãos de seu imaginário. Elas decerto seriam mãos fidedignas para a reconstituição, senão da beleza, da força expressiva daquele patchwork, embora não fosse exatamente isso... as suas paredes.

Se eu tivesse mãos artistas eu poderia realizar pelo desenho o que não sei fazer senão pelas palavras... Palavras, embora, insuficientes àquelas paredes gizadas... à pintura no uso doutra linguagem... simbolismo e grafismo, cuja tela poética evoca a estética urbana dos arredores do próprio bairro parisiense, em Barbès.

Através dessas mãos que não tenho eu poderia recontar... desenhando os traços, não propriamente, de uma arte, mas sobre a pluralidade de um estilo: um pensar, um viver e o sentir de um outro, de um mundo e de um outro mundo num outro... Esse outro que Johnny passou a ser, desde a sua chegada em Paris e através dessa pele estrangeira em condição refugiada.

\section{$* * *$}

Sua linguagem restituía os muitos fantasmas e moradores, outrora, no interior do prédio e do próprio homem que ele foi e que ele é. Fantasmas que sou capaz de ver e de relembrar de olhos bem fechados, embora inapta a representá-los, pois isto, é superior à capacidade impressa que tem uma folha de papel, a fim que ela possa revestir em palavras a caligrafia, a cartografia e a própria escrita encarnada... reencarnando vivos e mortos... naquelas paredes.

Johnny reconstituiu as proporções do antigo conflito - étnico, religioso e sobretudo político - o que divide o norte e o sul do Sudão: o seu país de origem.

Isto dito, ele apontou em direção à parede do fundo. Nela, uma sumária descrição em linguagem histórica e, eminentemente, política, embora nem por isso menos dramática ou ofensiva, acerca da guerra civil e do genocídio, durante meio século. Ao lado recortes de jornais, como também fotografias em preto-e-branco. Algumas manchetes marcadas por um grande e incisivo ponto de interrogação. Além das análises, uma, de uma revista britânica, a segunda, de um periódico francês e ambas assinaladas com tinta negra e uma grafia precisa: INTELECTUAIS! PECHINCHA BURGUESA! BLÁ-BLÁ-BLÁ EUROPEU! METRALHADORA DISCURSIVA! FABULAÇÃO DO REAL! IDEOLOGIA BARATA! MASTURBAÇÃO MENTAL. BRANCO QUANDO PENSA PRETO! PRETO SOB A TINTA BRANCA! MERDA! INVENÇÃO! SUB-VERSÃO! A MENTIRA CONTADA COMO VERDADE! INTELECTUALISMO 


\section{$=$ MEDIATISMO $=$ SENSACIONALISMO $=$ CAPITALISMO SEM MEDIDA E SEM LIMITE...}

[Tudoissoescritosemseparaçãoentreofimdeumapalav raeocomeçodaoutra]

[Como eu também e agora]

Compreender as revelações pela escrita de Johnny exigia paciência e, sobretudo, o abandono de um qualquer preconceito, estereótipo, concepções e categorias. Sua metalinguagem solicitava um certo esforço de reinterpretação e de releitura, pois a forma da escrita fugia, antes de tudo, às convenções do sistema da escrita ocidental e, muitas vezes, dos pressuspostos e regras da gramática francesa, pois, que muito se fez escrito em francês... e todo o resto em língua inglesa ou em língua materna.

A cartografia de Johnny senão a sua linguagem de resistência pela (e contra a) ordem, pela (e contra a) convenção do nosso sistema: o seu alinhamento horizontal no uso das palavras, a cumulação das frases da esquerda para a direita, do alto ao baixo da folha, quero dizer, da parede.

Sobre esse funcionamento (estrutural) da linguagem (a ortodoxia) que corresponde à própria (inteligibilidade) ou à uma possível inteligibilidade, pelo menos, quando se trata de uma escrita (ocidental, organizada, sistematicamente ordenada) e dada como uma espécie de modelo para o resto do mundo e, desse modelo, a linguagem construída sobre o Sudão e os países vizinhos.

Contra essa ordem a desordem para uma nova ordem:

a escrita pelas paredes; a leitura de Johnny; a reescrita pelos olhos de um refugiado

e, agora, a minha tentativa de reconstituição da memória - a sua memória - pela minha.

Johnny se contrapôs ao modelo ordenado dessa escrita convencional e, por meio dela a leitura de seu mundo.

Pelas paredes e, à sua maneira, uma linguagem exígua, a liberdade possível entre o desenho e a poesia ou entre as palavras e os segredos dos sentidos, que os desenhos sabem representar melhor através das paredes, antes, sem cor e sem vida, depois, paredes poéticas.

A primeira inscrição que pude ler, gravada na parede, bem no meio do quarto, foi feita através de uns escritos em Língua Hauçá; língua mãe e língua pai. A sua data corresponde à entrada de Johnny no quarto. Ao lado dela, um quadro negro, o substitutivo da agenda que ele não tem, mas por onde Johnny inclui - auxiliado por um giz branco - alguns números de telefone e os compromissos da semana. Segui a direção da flecha vermelha, pintada ao lado do apontamento em língua hauçá, e pela mesma cor, a caligrafia manuscrita. Ali, um segundo registo um tanto 
intimista e hermético... Johnny explicou-me certas condições e detalhes sobre o contexto da guerra civil, a sua adesão e o seu sentimento junto ao movimento revolucionário, durante as rebeliões quando jovem e, mais tarde, quando deixou o Sudão.

Tenho sempre os mesmos pesadelos. Eles me acompanham dia e noite... Existiria uma unica palavra entre as duas mil linguas africanas do meu Balad As $S \sqsubset$ daan (Sudão - País dos Negros), uma, para designar o que corrói e corrompe dentro de mim? Mas não me responda pelo uso de uma palavra vulgar. Quero uma; a palavra refugiada na savana, uma, camuflada na floresta, quem sabe, aquela se banha na bacia do Nilo e atravessa as fronteiras da geografia. "Geo grafia"a primeira grande mentira cientificamente estruturada e estruturante à vida dos homens. Todas as fronteiras serão intrinsecamente humanas. Apesar disso essa palavra escapa. Ela sobrevive à espera, num canto do mundo, pois ainda não se descobriu para os homens. Ela, talvez, murmure o seu nome no ouvido das mulheres. Aquelas mães sujas de sangue com pés descalços na planura. Aquelas mães sem filhos que se arrastam com pernas e braços pelas estradas do exilio: sempre mais longe, mais longe, onde nem olho, nem garganta renega ou tosse a poeira do Sudão. Longe, onde as deserdadas devem buscar refúgio, desde que foram aviltadas, mutiladas, violentadas e banidas... Quero uma expressão superior ao recalque. Uma palavra sobrevivente ao que persiste além do inesquecivel. Um vocábulo como é o da ferida aberta sobre a pele no campo de batalha. Outrora a justiça, agora, matase pelo desgoverno, pelo desatino, pelo gosto ou pelo que fica embrenhado na alma e nas mãos e vira cada homem pelo avesso. Vê-se, então, um homem de sangue e o sangue não é preto e nem branco, nem pobre e nem rico. $O$ sangue é a nossa universal idade, mas confundidos e usados, matamos e devoramos o nosso primeiro alimento - o sangue - a água do citoplasma - o ventre para o vício, o delírio para a loucura que se apossa de cada um, depois de tantas mortes com espada, faca, sabre, corda, tiro, pedra, machado, alfanje, foice, catana, pau ou, simplesmente, as mãos... Existe (?) ou o recalque assumiu a função dessa palavra refugiada... como eu também sou. Um refugiado. Um exilado entre esse eu do ontem e a ausência dessa palavra no presente. Existe tal vocábulo, expressão ou chamamento? Essa palavra permanece à sombra: grudada à lágrima interrompida, ao joelho dobrado, às pálpebras em oração, aos séculos atravessados pela ganância e às vidas secas sob o couro aturado pelo tempo da morte. A morte se misturou ao sangue mais que à própria vida e, por isso, ele se esparramou terra afora e avermelhou o próprio Nilo. Rio de uma infância perdida. Ela resiste como nódoa em pano usado. É palavra misturada ao sangue ou, talvez, ela própria é o sangue - dos soberanos, dos mandatários, dos oprimidos, dos soldados, dos guerrilheiros, dos revoltosos e dos meninos que morreram e morrem antes de se tornarem homens, pois que se 
misturaram (como todos os outros) à matança, à exterminação, e tanto matam, quanto morrem. Matam para sobreviver e depois, e depois? (Ah! essa palavra ausente) $O$ tabu. Esse buraco na linguagem, essa expressão sem lugar senão na dor que queixa sem queixar e, assim, o nascimento do recalque que, de certo modo, acalma... a lacuna sob mil nomes e formas que extrapolam os atos da perversidade humana, embora dentro de mim as mesmas imagens se repetem e se repetem e se repetem. Pesadelo. Noites a fio. Noites a dentro. Prefiro a insônia. Imagens que perduram além do inesquecivel, além da memória e do branco na memória... Qual palavra substituiria: o esquecimento? Qual palavra, qual não existe, qual me corrói, todos os dias, e me lembra sobre as minhas mãos... sujas de sangue, a minha vitória... a minha derrota, o meu que é um e'u pelo m'eu Su'dão - o Sul de Adão desafortunado, dividido, banido e delido como EU, agora, e'u. Estou apartado pelo Sudão que resta, embora sei que uma velha do país vai, então, reunir meus cacos. Ela vai guardar os restos e, deles, fará um vaso de mesa para, depois, retirar dentro dele a areia, da areia a terra do conto e da lembrança e, desse modo, o que ela sabe para contar aos mais moços para que eles, também, saibam sobre o que era o país e o que dele foi feito.

\section{(...)}

Johnny concluiu a leitura, traduziu devagar, embora o texto, ele o sabia de cor, em Língua Hauçá, apontado com tinta vermelha e uma letra miúuúda, apertadíssima; a falta de espaço entre os desenhos, recortes e colagens, como se o texto fora inscrito mais tarde no coração da parede à frente da janela. Ele se deitou sobre o tapete e, de lá, arrematou umas frases... Parecia improvisar e, ao mesmo tempo, divagar. Aumentava o que não coubera naquela parede minúscula, grotesca, úmida e insensível à sua catarse.

A expressão sem lugar se perdeu no silêncio. Dirigiu o olhar para o interior do Sudão, através do mapa que, ele mesmo, havia desenhado sobre a cabeça do quarto - o teto. O Sudão fora apontado em vermelho, além das cores em tom verde, azul, amarelo, preto e branco. Apontou para o noroeste, a fronteira com a Líbia, para o norte, o limite com o Egito, à leste, o Mar Vermelho e a Eritreia, do outro lado, a Arábia Saudita e, num piscar de olhos, a sua travessia para a Etiópia. Ao sul, os casos relembrados em Uganda e no Quênia, depois, um terceiro incidente com os rebeldes que tentaram a sorte na República Democrática do Congo. No oeste, ajudado pelo dedo indicador, mostrou-me a República Centro-Africana e o Chade e, finalmente, Cartum, a capital sudanesa... pronunciada como quem diz o nome da amante...

Detalhou alguns passos do grupo de resistência a que pertencera, embora diluídos junto ao vapor, durante o cozimento dos legumes com os 
quais ele preparou uma suculenta sopa... O nosso primeiro jantar servido sobre o tapete, ao lado do lampião, em duas cumbucas de cerâmica tradicional, com pão dormido molhado no caldo, a colher buscando o lado da louça e a minha língua cheia de cuidado pra não me queimar.

... Recapitulou, numa outra ocasião, certos aspectos e estratégias de ataque, fuga, emboscada, como também o que conhecia das traições e o que acontecia com os traidores. Nesse dia eu tive medo! Ele soube. Percebeu. Talvez, assim, o quisesse. Um contar premeditado. Calibrar o diâmetro de minha alma sobre a boca-de-fogo; o seu assunto longo e esmiuçado. Afiar a coragem. Desafiar o meu receio. Testar o seu masculino às custas do meu feminino. Buscar o seu rastro e acerca dele o meu limite; a linha fronteiriça se eu a tivesse demarcado e, se eu pedisse que parasse por ali, e que ele me deixasse em paz, afinal, a guerra era mais sua do que minha! Eu nada fiz, senão escutar e responder com os olhos, apreender com todos os sentidos despertados pela sua história até, ele mesmo, se cansar e aludir sobre as vitórias e a solidariedade do movimento popular.

Engolimos tudo, soprando lentamente o café nas canecas de lata latão batido - como no tempo da minha infância e ao longo de sua vida. Tudo consumido na quentura do preto e nada mais. Ah café que me salvou da água na bacia das almas... Tanta morte contada... Tanto pormenor aludido... Tanta matança ao alcance dos meus olhos... Tanta lembrança aquecendo o seu sangue... a água do citoplasma naquele Johnny - o seu sangue, ainda mais estrangeiro, quando em arapuca através de tantas lembranças.

$\mathrm{O}$ assunto morreu entre nós. Foi sepultado, conforme a antiga tradição na aldeia de seu pai; como eu pude aprender naquele mesmo dia. Nos velórios, a palavra nasce somente através da cantoria, choro de carpideira como se vê no Velho Chico... rio e secura... não tem só no lado de lá. Choro de lamentação como cantam as mulheres em seus véus brancos ou negros... não tem só no lado de lá. Tradição nordestina pelas carpideiras do Brasil do Alto... não tem só no lado de lá. O que se tem e quando muito é o barulho de um gole de bebida, o acender do fogo, o cruzar das velhas, a partilha do pão, alguma folha do mato para incensar a casa e o silêncio comandado pela devoção entre os que saem e os que revezam. Por fim, a despedida, lágrima em lenço de pano; o recato sempre na frente, muito respeito pelo morto, embora maior zelo para com os que nesse mundo ficam.

... Depois de muitas vezes: visitas, encontros e imprevistos acabei por perguntar-lhe sobre a família, embora pouco foi dito, pois se tratava de assunto por demais delicado. 
O amor havia cumprido o improvável. Assim também do outro lado da fronteira. Assim também no mundo pelo mundo do Sudão.

A mãe teria herdado traços, bens e uma educação inconfundivelmente árabe, segundo Johnny. A primeira língua e a cultura, a de seus ancestrais muçulmanos há muito instalados no norte do Sudão. Contudo ela se opôs ao controle e ao domínio dos cristãos e dos animistas no sul do país. Transgrediu os costumes, os ensinamentos e o seu destino no seio da tradição e foi, por essa razão, deserdada e castigada. Disfarçou-se de homem, frequentou o grupo de rebeldes, aprendeu a lidar com armas, fugiu e rebelou-se contra o massacre dos zurgas no oeste do país. Pagou por isso. Sofreu com a exterminação de mais de quatrocentos mil crioulos e a expulsão de outros dois milhões pela Frente Islâmica Nacional. Lutou veemente contra os excessos, os abusos e as contradições humanas incutidas em nome da Sharia, a lei islâmica, ou o que dela dizem ou querem certos homens num certo poder local ou global.

Lutou, portanto, contra os espólios contraídos nos assaltos contra os de pele negra, o êxodo que sofreram, os enforcamentos, as mutilações, o genocídio, a liberação do álcool e a política do caos como prática instituída, acima de qualquer direito humano e sem a devida intervenção dos países "mais desenvolvidos" do ocidente. Teve pois o corpo queimado; a represália comandada pela própria família e

isto dito

nada mais foi acrescido por Johnny.

Um dia, ao perguntar pelo pai, ele respondeu com ironia:

Bem, esse é o ponto-chave da minha história. Daí em diante tudo mais curioso como também turbulento. É o mínimo que posso dizer, desde a união entre minha mãe e meu pai. Vida tumultuada, violenta e intranquila. Ele, um cristão negroafricano, além de detentor de um amplo conhecimento sobre a antiga Núbia, pelo menos, em sua mente privilegiada de homem culto! Meu pai foi o que chamam de autodidata. Uma mente excepcional, mas que nascera do lado errado; do lado que perde e, que foi escolhido para perder! Meu pai sabia os pormenores sobre aquela região, antes e depois que o Sudão foi incorporado ao mundo árabe, durante a expansão islâmica no século VII.

Se tenho Mahdi, como parte do nome, foi por capricho e atrevimento paterno. $O$ apelido, ora conchavou, ora conspirou contra o meu próprio destino... Como sabe, cada um interpreta a história com o par de lentes que tem: inteiras ou partidas. Assim, carrego a alcunha, daquele que foi o líder pela expulsão inglesa em 1885. Muhammad Ahmed bin' Abd Allah, conhecido como Mahdi, morreu não muito tempo depois e, desse modo, os ingleses recuperaram o Sudão, em 1889.

$O$ amor proibido de meus pais definiu a travessia: o nomadismo para as terras 
do sul, até a tribo de Dinka, onde nasci, algum tempo depois, nos arredores de Juba e Bor.. O coração selvagem banhado pelo Nilo Branco. O lugar das nuvens brancas, macias e tangíveis nos pés de algodão e, assim, as poucas imagens que guardo e me causam profunda nostalgia e alegria.

... Envolvi-me com o grupo de resistência coordenado pelo movimento de liberação do Sudão, mas isso já era mais que esperado e seria traição não fazêlo! Não hesito em dizer-lhe, antes que me questione ou, ao contrário, antes que você recolha a pergunta para semear a dúvida... Eu afirmo: não há uma única personalidade ou um simples civil, em qualquer esfera da vida politica, as do poder instituído ou as que participam das forças excluidas de poder, que não tenha mãos sujas, inclusive, no Sudão. Eu poderia estender esse princípio para o resto da África, em todo o seu vasto continente e ao longo de sua história... As minhas mãos, se tivesse cinco pares delas, todas, irremediavelmente, sujas de sangue. Meu coração, se resistiu, ele é apenas um sobrevivente entre as mãos que tenho. Não me compadeço, não me vanglorio, nada disso ou seu contrário.

Existem mãos lisas, finas, brancas, sem marcas da vida e, por demais, conservadas. No entanto se são mãos limpas? Já não sei. Provavelmente não, sobretudo, quando se trata de ambição, dinheiro, poder e controle. Mediante certas circunstâncias e essas condições da escolha humana tudo recai sobre a dizimação, a crueldade e a violência, inclusive ou, principalmente, através daqueles que cruzam os braços e lavam as mãos.

Quem esqueceu essas coisas é, suficientemente, perverso, sádico e covarde. A angústia face à morte (se ele a tiver, pois há gente de todo tipo e, tipos bem singulares! que você desconhece completamente. Há gente que perdeu a alma, a vida, o laço com o lugar onde riu pela primeira vez... o nó que o amor cria e que deixa em cada um como uma possibilidade de ser mais forte para não matar). Talvez, um covarde, e, talvez, nesse caso, a morte e o que ela causa ao covarde, talvez, a morte arranque dele alguma confissão... Arranque uma palavra conjuntiva e adiposa, talvez, arrebatada pelo que se pretendeu vencido e enterrado em sua terra estéril; o ventre vazio...

Eu fugi... Naquele momento eu estava convencido que eu seria mais útil e teria mais valor se melhor vivo e se melhor distante. Meu pai acreditou que eu pudesse estudar e militar do outro lado do mundo; do lado em que o mundo de cá decide sobre o de lá e, isto se faz, com estudo, ao lado do poder, por meio das alianças e do dinheiro que se tem no bolso.

... Fui estúpido em acreditar que a minha vida poderia ter sentido noutro lugar. O espaço de luta, de resistência, de reação e discussão política e solidariedade internacional eu, de fato, nunca encontrei, nunca, nem em Paris, nem em Londres, nem na Alemanha, nem na Suiça... 
Em uma visita, num dia de domingo, li em voz alta a frase pintada na parede, onde Johnny havia justamente amparado as suas costas.

Le voyage est une suite de disparitions irréparables

(A viagem é uma sequência sobre as perdas irreparáveis)

Ele logo completou:

Paul Nizan não nos surpreende tanto através dessa afirmação, mas a frase é, sem dúvida, sublime! Embora, ela, só faz sentido para os que atravessam (uma outra) fronteira (e muito mais subtil) ao longo da viagem. Não me refiro aos ávidos por turismo, fotografia e cartão postal. Aos que celebram os quilômetros percorridos entre o mesmo ponto de partida e o de chegada. Uns imbecis com as suas máquinas de filmar e seus guias de viagem! Não penso tampouco nos que percorrem o mundo inteiro e descrevem o caminho, estritamente, pelas conquistas e descobertas com a geografia, a culinária, a arte, a cultura ou a música desse ou daquele país. Miopes! Toupeiras, apesar de seus recursos tecnológicos, suas pujantes objectivas e câmaras de última geração! São colecionadores de fotografias, boas ou péssimas. São consumidores de souvenirs, de t-shirts, de chaveiros, carteiras, buttons e bonés. Recorrentemente cortam pés e cabeças dos autóctones ou dos estrangeiros que entrarão em seus álbuns de fotografia! Quando não cortam as próprias cabeças ou os pés das esposas, dos filhos e dos companheiros de viagem! Ah esses turistas de ocasião! Itinerantes sem assunto e sem experiência senão sobre as lições aprendidas com os guias de viagem - os INCLUÍDOS - pelos pacotes das agências de turismo, com seus hotéis de $5^{a}$. e uma comida de cantina! Viandantes do pós-guerra como quer o capital de ontem, o de hoje e o consumismo em aceleração. Quem disso foge é considerado como "obsoleto", "pré-histórico", "conservador", "analfabeto urbano", "iletrado em pós-modernismo" e sai de baixo, não faltam estereótipos, pois atrás e na frente lá vem os turistas com celulares, câmaras, bonés e muita etiqueta dos pés à cabeça! Eles atravessam o mundo inteiro com olhos turvos senão fechados... Sabem do lugar onde vão pelos livros. O que sabem nasceu da ortodoxia ditada em livros, enciclopédias, guias e mapas impressos e virtuais. Conhecem onde vão (e para onde não vão) sem conhecerem nada por dentro; sem o reconhecimento do interior pelo interior.. sem o pré-conceito ambulante... sem as categorias préfabricadas... sem as publicidades... sem as promoções das agências de viagem... e a metralhadora afiada da mídia.

Esses legitimos e inveterados passeadores percorrem o planeta, através da diligência de seus passaportes, da assistência do sistema capitalista, através de seus múltiplos mecanismos de inclusão e de exclusão. São passeadores encomendados pelas regras explícitas e implicítas às políticas financeiras pelo bem-estar do capital $e$, assim, essa gente enlatada segue e digere como comida cultural: marcas, lugares, museus, igrejas, fotografias, lembranças de viagem, presentes baratos e guias de bolso. 
$E$, assim, quando retornam ao país de origem eles servirão para visitas e convidados toda essa comida enlatada: o laticinio urbano e turisticamente engendrado pela liberdade do capital para os que têm meios para pagar seus desejos ou que têm meios para se endividarem ano a ano. Exibirão com orgulho à familia, aos amigos e aos colegas de trabalho as fotografias, os vídeos, as compras, os últimos lançamentos $e$ objetos de consumo adquiridos durante suas "viagens".

... Encontrei em Paris, alguns viajantes que passaram pela inscrição de Paul Nizan. Refugiados, visionários, imigrantes, mochileiros e andarilhos que sabem do que se trata... uma viagem dentro da viagem...

Um imigrante, por vezes, sofre seus bocados e paga pela esponja grossa e permeável, através da qual esfrega e de tanto esfregar julga apagada a marca de seu exílio. Optam pelo conforto da adaptação e da integração.

Escondem-se como cachorros loucos! Embranquecem os traços de origem cultura, língua e pátria - e pintam com as cores da nova bandeira seus dias e suas descontinuidades.

Eu os compreendo. A declaração da dor (carregá-la em si mesmo) pode ser um fardo e, em certas circunstâncias, insuportável! Mas a covardia, a negação, a cultura como consumo, a falta de consciência pela alienação é qualquer coisa que...

(...)

Johnny elegeu uma segunda frase, a de Proust: Tout homme d'amour est un homme de douleur (Todo homem de amor é um homem de dor).

Porque elegeu essa frase entre tantas pintadas na parede?

Esta língua, qual o fôlego de Proust, é ainda mais caprichosa do que se mostra na vida corrente. O amor qual ele seja expõe de fato o nosso desejo e a nossa cicatriz. Ninguém (salvo, quando mutilado) é radicalmente louco para fugir do amor ou do desejo, embora, muitos têm fugido ou dissimulado as suas marcas de imigração... Confronto o amor e o exílio como faço e posso, muitas vezes, deitado, aqui, diante desse pedaço do mundo e de outros por onde vivi.

Porém, Jean Cocteau, decifrou pelo verbo o amor... "Le verbe aimer est difficile à conjuguer: son passe n'est pas simple, son présent n'est pas indicatif et son futur est trés conditionnel" (O verbo amar é difícil de conjugar : seu passado não é simples, seu presente não é indicativo e seu futuro é condicional).

Há quem ama um outro ou uma outra. Há quem ama um sonho e por ele tudo abandona. Há quem ama, abandonando, sucessivamente, porque tem medo do amor. Há quem se agarra ao desejo até sem amá-lo... É duro demais olhar para trás (eu sei!) e o orgulho, às vezes, tantas vezes, reclama a sua parte...

Amar é impreciso como a própria viagem, em particular, a viagem determinada pelo exilio. 
...Encontrei há alguns meses um jovem da Martinica, portanto, um francês do ultramar. Gosto muito do rapaz. Ele é descontraído, inteligente, sensivel e culto, embora muito jovem integrou alguns preceitos e aprendizagens para sofrer menos, mas sem se desnaturalizar...

Trata-se de um rapaz honesto e muito virado, principalmente, em linguagem informática. Tem diploma, tem estudo, tem família, mas não arranja emprego. Seu francês é impecável, como seus documentos, sua carteira de identidade e sua recente formatura... Nada de sotaque ou qualquer insígnia de distinção sobre sua origem, SALVO, uma! Ele é negro! O gajo, portanto, já foi muitas vezes controlado e interpelado pelos policiais do bairro, pelos seguranças que percorrem as estações de metrô e ônibus, enfim...

Um dia, entrou pelo café, cabelo curtíssimo, sem barba, uns óculos de intelectual e sapatos nos pés. Largou a cabeleira, limpou a cara, tirou dos pés o par de tênis e anda sempre com um livro na mão: de direito, de política, de filosofia... ou sociologia. O conteúdo não interessa muito, o importante é trazer consigo um livro; você entende?

O cara não vai se pintar de branco e não vai trocar de sobrenome! Contudo, depois da mudança visual (e o golpe de mestre: trazer consigo um livro grosso ou de um autor reconhecido!) nunca mais o sujeito foi barrado no baile, no trem ou na rua... Entretanto, depois de sessenta e tantos currículos distribuidos, dentro e fora de Paris, ele continua sem emprego, apesar de ter passado por uma dezena de entrevistas e ter um bom $C V$.

Decidiu, então, abrir o proprio negócio, ou seja, explorar seus talentos virtuais. Assim, o ecrã virou seu patrão. Por detrás da tela mágica o rapaz não apenas encontrou um meio de trabalho como já emprega três ou quatro árabes que, como ele, viviam desempregados. Todos, marginalizados pela mesma ou outra versão da história, ligada à origem, à cor da pele, à crença religiosa ou à marca de nascimento atrás do sobrenome.

$* * *$

Numa tarde, reunido um pequeno grupo, fomos almoçar com Johnny, no seu quarto. Levei a composição de uma das canções de Alain Souchon e Laurent Voulzy: C'est déjà ça. (Pelo mesmo isso!) O título, repetido e repetido, ora pergunta, ora resposta, reflexão e contradição canta o desejo e a conquista de um imigrante no cenário urbano e europeu. Pareceram-me apropriadas a afirmação e a ambiguidade incitadas pelo texto da canção. Belleville como cenário, Pelo menos isso, refrão e título, contexto e conteúdo, sobre um outro sudanês no exílio.

Cantamos, solfejamos, dançamos até que a melodia redefiniu a memória e o encontro. $\mathrm{O}$ talento dos que sabiam se servir da tinta, do 
pincel e do spray transformou o quarto: o criado-mudo, a borda do espelho, o caixote, os cabos das panelas, a mala, o vão da entrada, os ângulos das paredes, o rodapé, e, no final, o que antes no quarto era demasiado tristonho e desbotado ganhou cores novas: rosa, laranja, verde limão, tiatã, turquesa e violeta.

À nossa maneira o extravasamento coletivo contra a morte de John Garang, líder do APLS, vítima de um "acidente de helicóptero" na semana anterior. Sabíamos que a fatalidade pesava sobremaneira em Johnny e, certamente, sobre a população sudanesa. Em Cartum, como também em Juba, reabertos os confrontos entre a milícia e os manifestantes. Além disso, não se tratava apenas da morte do fundador da Armada Popular pela Liberação do Sudão. O seu acidente ou assassinato (?) comprometia o acordo pela paz, portanto, intimidava a composição de um novo governo em prol da unidade nacional.

A melodia, a letra, o fato de cantarmos bem alto e juntos acabou por sensibilizar Johnny. Ele assistiu embevecido as marcas, as cores e os desenhos aliados aos seus. Aquilo, talvez, tenha aberto alguma esperança em seus olhos de antílope. Falou pouquíssimo. Preferiu cantar. Reservou um canto da parede. Desenhou um saco plástico, pintado de preto e em pleno vôo pela rua. Ao lado, através de sua bela caligrafia, uma mesma frase em árabe, inglês, dinka, hauçá, beja, nuban e francês:

certains jours on se sent très seul (certos dias a gente se sente muito só)

Nenhuma pontuação no meio ou no fim da sentença. A frase iniciada sem letra maiúscula, suspensa como o saco negro, ambulante, errante, instável, passageiro e livre pelas ruas de Belleville - plástico negro - como repetiam os versos da canção.

Pedi, então, ao colega do lado que desenhasse o pássaro no quintal da minha infância. Ele reproduziu pela ponta do pincel o que eu ditei pela cabeceira da memória. Ele o fez e ao lado do saco plástico desenhado por Mahdi.

Em nossa região o bichinho era conhecido por t-ziu. Uma espécie de pardal, porém, todo negro. Muitos deles vinham visitar os quintais e se apossavam, na ocasião, dos galhos das árvores. Vinham, em bando, cinco, dez, tantos e indistintos em nosso bairro: longe, novo, quase sem residências, todo em terra batida e muito vermelha.

$\mathrm{Eu}$, no entanto, conhecia bem um; unzinho em linguajar de criança! Escolhia sempre o mesmo. Imaginava, então, esse $t$-ziu, um único, durante a cantoria que atravessava os quintais como um coro de igreja.

A sua natureza de pássaro preto (indistinto a olho nu) inventou um canto (só dele) que repetia e repetia até cansar e voar: t-ziu, t-ziu, t-ziu. 
Durante a cantoria a sua particularidade: a difícil acrobacia que aquele bichinho fazia. À medida que piava $t-z$, ele saltava, fazia a sua cambalhota, tornava a pousar no galho e concluía o pio: $i u$. Toda a meninada ouvia, boca aberta, em silêncio, até o fim da proeza entre o som e o salto. A coordenação graciosa e sonante naquele pássaro preto, que a molecada insistia em chatear, com seus bodoques, estilingues, espingardas de chumbo, arapucas, gaiolas, alçapões, pedras e atiradeiras...

Inconfundível, agora, aquele único pássaro de cada dia, através do talento do pintor. O meu T-ziu ganhou uma outra existência: um galho, num arbusto, num bairro, ao lado de um saco plástico e negro, onde voam, pássaro e saco e, o bichinho, canta, rodopia e descansa entre as carreiras do vento.

Paris, 07 de Agosto de 2005

Para Johann Mahdi, onde estiver.

Johnny deixou o quarto, talvez, no dia seguinte. Ninguém soube. Ninguém

viu.

Catitu Tayassu

Curadora e Diretora do Fundo Web Internacional - Pour la Vie Ailleurs \& Pour la Vie Maintenant - Pela Vida Afora \& Pela Vida Agora. Fundadora da Associação Vie Ailleurs \& Vie Maintenant, em Paris, dedicada à salvaguarda e à difusão das línguas, dos povos, culturas, saberes e expressões orais e ancestrais. E assim o seu sonho individual em realização coletiva para uma "Mémória Viva" $e$ ao acesso de todos em prol do Patrimônio Imaterial da Humanidade. Esse fundo arquivistico será lançado em 2011, através de um site oficial intitulado "Terra em

Mémória - Terre en Mémoire - Landy in Memory - Tierre en Memoria" www.pourlavieailleurs.org 